\title{
Closing the Loop: Use of Biochar Produced from Tomato Crop Green waste as a Substrate for Soilless, Hydroponic Tomato Production
}

\author{
Samuel J. Dunlop \\ Institute of Agriculture and Environment, Private Bag 11222, Massey \\ University, Palmerston North 4442, New Zealand
}

Marta Camps Arbestain and Peter A. Bishop

New Zealand Biochar Research Centre, Institute of Agriculture and Environment, Private Bag 11222, Massey University, Palmerston North 4442, New Zealand

\author{
Jason J. Wargent ${ }^{1}$ \\ Institute of Agriculture and Environment, Private Bag 11222, Massey \\ University, Palmerston North 4442, New Zealand
}

Additional index words. biochar, soilless, hydroponics, tomato

\begin{abstract}
Greenhouse tomato (Lycopersicum esculentum Mill.) producers are urged to reduce their environmental footprint. Here, the suitability of biochar produced from tomato crop green waste as a substrate for soilless, hydroponic tomato production was evaluated. Substrates containing different combinations of biochar (BC) and pine (Pinus radiata D. Don) sawdust (SD) were produced (BC0-SD100, BC25-SD75, BC50-SD50, BC75-SD25, and BC100-SD0) and characterized. The effect of these substrates on tomato growth, yield, and fruit quality was studied. Most of the measured properties of substrates containing biochar were suited to use as a soilless substrate. The electrical conductivity (EC) of substrates containing biochar was initially high $\left(>4.6 \mathrm{mS} \cdot \mathrm{cm}^{-1}\right)$, but was easily reduced to $<0.5 \mathrm{mS} \cdot \mathrm{cm}^{-1}$ by rinsing with water before use. The $\mathrm{pH}$ of substrates containing biochar was higher than is considered acceptable for tomato production $(7.5-9.3)$ but did not significantly $(P<0.05)$ affect any plant growth, yield, and fruit quality indicators measured compared with those of plants grown in pine sawdust. The results support the concept of creating a closed loop system whereby biochar produced from tomato crop green waste is used as a substrate for soilless, hydroponic tomato production, providing a sustainable means to support the growth of high-value food crops.
\end{abstract}

Food producers currently face considerable financial challenges related to rising energy and input costs. In particular, those foodstuffs produced indoors under glass, or in other protected environments (e.g., polytunnels) accounts for more than 650,000 ha of food growing land area (ISHS, 2012), yet are subject to unique and significant challenges. For example, the sustainable disposal of crop waste is recognized as a major challenge, particularly for indoor-produced crops (Urrestarazu et al., 2003). This includes polypropylene string, used growing substrate, crop green waste, and considerable quantities of plastic arising from ubiquitous use of substrate containers and crop slabs. Glasshouse growers additionally face considerable pressure from retailers and consumers to better manage energy, inputs, and waste to

Received for publication 8 July 2014. Accepted for publication 16 Dec. 2014.

${ }^{1}$ Corresponding author. E-mail: j.wargent@ massey.ac.nz. impact and economic costs associated with transport (Neocleous and Polycarpou, 2010).

The use of biochar [charcoal-like material produced by heating biomass in the absence of oxygen $\left(\mathrm{O}_{2}\right)$ ] produced from glasshouse crop green waste as a substrate for soilless, hydroponic plant production could provide growers with a cost-effective and environmentally responsible green-waste disposal method, and supplement substrate, fertilizer and energy requirements. Although the use of carbonized materials as soilless substrates is currently not common in commercial practice, carbonized rice hulls have been used in Japan for more than 40 years, and in Brazil since the early 1980s (Ikeda, 1985; Kämpf and Jung, 1991). Other carbonized organic materials that have been studied for use either on their own, or more commonly as a substrate component include rice straw, sawdust, coco coir, wheat straw, malt grains from brewery waste, coffee husks, citrus wood, and forestry residues (Canizares et al., 2002; Dumroese et al., 2011; Graber et al., 2010; Guerrini and Trigueiro, 2004; Nishimura et al., 2009; Pires et al., 2009).

Those few initial studies to date generally indicate that the performance of plants grown in substrates containing, or consisting entirely of carbonized materials is generally comparable or better than those grown in more commonly used substrates (Kämpf and Jung, 1991; Lee et al., 1999; Ruifen et al., 1991), although negative effects on plant performance have also been reported (Carrijo et al., 2004; Inden and Torres, 2004). There is very little published information regarding the effect of soilless substrates containing, or consisting entirely of carbonized biomass on plant nutrient status, although there are some indications that such substrates may have an effect on nutrient content (Peyvast et al., 2010). Moreover, when added in small quantities $(1-3 \% \mathrm{w} / \mathrm{w})$ to a fertigated, soilless substrate, biochar has been shown improved the growth of tomato, and growth and yield of pepper (Graber et al., 2010) and a less incidence of necrotrophic and biotrophic foliar pathogens has been observed (Elad et al., 2010).

The aim of this study was to compare the performance of tomato crop green-waste biochar as a soilless substrate for hydroponic tomato production with an existing, commercially acceptable substrate material, pine sawdust. Mixtures of biochar and sawdust at different ratios were also studied to identify the likeliness of any dose effect related to the use of biochar as a substrate. Our hypotheses were that 1) the chemical and physical properties of substrates containing, or consisting entirely of, biochar produced from tomato crop green waste will be suitable for hydroponic tomato production, 2) the growth, yield, and fruit quality of tomato plants grown in substrates containing, or consisting entirely of, biochar produced from tomato crop green waste will not be significantly different from those grown in pine sawdust. Enhancing our understanding of the possibilities for introducing sustainable high-value 
food crop media substrates could provide a valuable step forward in global food production.

\section{Materials and Methods}

Production of biochar from tomato crop green waste. Tomato crop green waste, consisting primarily of vines removed at the conclusion of a typical production season, was obtained from a commercial greenhouse cherry tomato grower in the Manawatu area (North Island, New Zealand). Our green waste also contained the stem clips and string used to train tomato vines during the production cycle, which accounted for $\approx 7.5 \%$ of green-waste dry weight. No attempts were made to remove the polypropylene stem clips and string used to train tomato vines during the production cycle as this would be impractical in a commercial situation. According to the International Biochar Initiative Guidelines (IBI, 2012), feedstock used for biochar production cannot contain $>2 \%$ contaminants (e.g., fossil-fuel derived products) on a dry weight basis. The amount of contaminants present in our feedstock thus exceeded that established in the abovementioned guidelines. To compensate for this, incorporation of another form of biomass, such as sawdust, into the feedstock could be applied to dilute the mass of stem clips in the feedstock $<2 \%$ in the future. A prior study showed the almost complete thermal decomposition (to $\approx 0.5 \%$ of the total tomato biochar mass) of the stem clips and string in the absence of $\mathrm{O}_{2}$ when the temperature of the kiln reached $450{ }^{\circ} \mathrm{C}$. A final heating temperature of $550{ }^{\circ} \mathrm{C}$ was chosen for the production of biochar for this study, as this higher pyrolysis temperature 1) minimizes the likelihood of contamination of biochar from stem clips and string contained in the green waste, 2) reduces the risk of nitrogen (N)-immobilization [e.g., low fraction of labile carbon (C)], and 3) had superior wettability characteristics as compared with a biochar produced at a lower temperature.

The green waste was first air dried and then pyrolyzed in two batches using a wood-fired, twin kilned, static bed retort pyrolyzer with a total kiln capacity of $2 \mathrm{~m}^{3}$. The temperature of the kiln was controlled by stoking the fire to increase temperature, and flaring off syngas from the retort system to maintain or decrease temperature. There was a considerable variation in the temperatures achieved within this kiln during the pyrolysis of the second batch (ranging from 440 to $550{ }^{\circ} \mathrm{C}$ ). Once produced, the biochar was roughly graded by forcing it through an 8-mm sieve. Following this the two batches were thoroughly mixed together.

Preparation of substrates. Substrates were prepared consisting of biochar, sawdust, or mixtures of the two materials. Sawdust was sieved, as for biochar, through an 8-mm sieve. The following biochar (BC)-sawdust (SD) mixed substrates were prepared on a dry weight (w/w) basis: 1) BC0-SD100, 2) BC25SD75, 3) BC50-SD50, 4) BC75-SD25, and 5) $\mathrm{BC} 100-\mathrm{SD} 0$ - the number following $\mathrm{BC}$ or

Table 1. Stock solutions used for seedling trial and main growth trial fertigation programs. Each stock solution was made by mixing fertilizer materials with $100 \mathrm{~L}$ of water.

\begin{tabular}{|c|c|c|c|c|}
\hline \multirow[b]{3}{*}{ Nutrient source } & \multicolumn{4}{|c|}{ Concn in stock solution $\left(\mathrm{g} \cdot \mathrm{L}^{-1}\right)$} \\
\hline & \multicolumn{2}{|c|}{ Fertilizer solution one } & \multicolumn{2}{|c|}{ Fertilizer solution two } \\
\hline & Part A & Part B & Part A & Part B \\
\hline \multicolumn{5}{|l|}{ Macronutrients } \\
\hline Calcium nitrate $\left[\mathrm{Ca}\left(\mathrm{NO}_{3}\right)_{2}\right]$ & 170 & - & 170 & - \\
\hline Calcium chloride $\left(\mathrm{CaCl}_{2}\right)$ & - & - & 40 & - \\
\hline Potassium nitrate $\left(\mathrm{KNO}_{3}\right)$ & 90 & - & 120 & - \\
\hline Monopotassium phosphate $\left(\mathrm{KH}_{2} \mathrm{PO}_{4}\right)$ & - & 35 & - & 40 \\
\hline Potassium nitrate $\left(\mathrm{KNO}_{3}\right)$ & - & 90 & - & 120 \\
\hline Potassium sulphate $\left(\mathrm{K}_{2} \mathrm{SO}_{4}\right)$ & - & 35 & - & 40 \\
\hline Magnesium sulphate $\left(\mathrm{MgSO}_{4}\right)$ & - & 130 & - & 130 \\
\hline \multicolumn{5}{|l|}{ Micro nutrients } \\
\hline Iron chelate (FeEDTA) & 5 & - & 5 & - \\
\hline Manganese sulphate $\left(\mathrm{MnSO}_{4}\right)$ & - & 1.25 & - & 1.25 \\
\hline Zinc sulphate $\left(\mathrm{ZnSO}_{4}\right)$ & - & 0.5 & - & 0.50 \\
\hline Copper sulphate $\left(\mathrm{CuSO}_{4} \cdot 5 \mathrm{H}_{2} \mathrm{O}\right)$ & - & 0.15 & - & 0.15 \\
\hline SoluBor $(25 \%$ B) & - & 0.75 & - & 0.75 \\
\hline Sodium molybdate $\left(\mathrm{Na}_{2} \mathrm{MoO}_{4} \cdot 2 \mathrm{H}_{2} \mathrm{O}\right)$ & - & 0.02 & - & 0.02 \\
\hline
\end{tabular}

SD indicates the percentage of biochar or sawdust in the substrate. The 11-L module bags were filled with the equivalent fresh weight of prepared substrates.

Once filled, the substrate modules were pretreated to overcome any water repellence and reduce soluble salt content. This involved filling the substrate modules with tap water. The modules were then allowed to soak for $48 \mathrm{~h}$. After this period, the substrate modules were allowed to drain thoroughly for $\approx 8 \mathrm{~h}$. Following this the modules were continuously irrigated with tap water for $48 \mathrm{~h}$ via a drip irrigation system, with EC of the drainage water checked periodically. After $48 \mathrm{~h}$ of leaching, the $\mathrm{EC}$ of the drainage solution from the BC100-SD0 modules, which had the highest EC of all substrates, was $\approx 0.5 \mathrm{mS} \cdot \mathrm{cm}^{-1}$. At this point, the substrate modules were fertigated (Tables 1 and 2) and allowed to drain thoroughly before transplanting seedlings.

Biochar characterization. Total $\mathrm{C}\left(\mathrm{C}_{\mathrm{total}}\right)$, total $\mathrm{N}\left(\mathrm{N}_{\text {total }}\right)$, and total hydrogen $(\mathrm{H})$ content were determined using a CHNOS elemental analyser (Vario Macro Cube, Hanau, Germany). Ash content was determined by thermogravimetric analysis (SDT Q600; TA Instruments, Melbourne, Australia) following the method of Calvelo Pereira et al. (2011). Inorganic $\mathrm{C}$ was determined following the method of Bundy and Bremner (1972). The $\mathrm{pH}$ was measured following the method of Ahmedna et al. (1997) in a suspension of oven-dried, ground biochar in deionized water (ratio of 1:100; w/w). Calcium carbonate equivalent $\left(\mathrm{CaCO}_{3}\right.$ eq. $)$ was determined by a modified version of the rapid titration method (Piper, 1950). Wettability was determined using the water drop penetration time test (WDPTT) according to the method of Letey (1969). Cation exchange capacity was measured following a modified version of the method of Matsue and Wada (1985) using $0.01 \mathrm{M}$ strontium chloride. Formic acid-extractable phosphorous (FA-P) was used to indicate plant available phosphorus $(\mathrm{P})$ in biochar following the methodology described by Wang et al. (2012).

Substrate characterization. Air-filled porosity (AFP) and water-holding capacity (WHC) of the substrates were measured
Table 2. Approximate concentrations of macronutrients in fertigation solutions used for seedling growth trial and main growth trial. For both the seedling trial and the main growth trial stock solutions were diluted $(\approx 1: 100 \mathrm{v} / \mathrm{v})$ with water before application to plants.

\begin{tabular}{lcccccc}
\hline & \multicolumn{6}{c}{ Concn (ppm) } \\
\hline $\begin{array}{c}\text { Fertilizer } \\
\text { solution }\end{array}$ & $\mathrm{N}$ & $\mathrm{P}$ & $\mathrm{K}$ & $\mathrm{Ca}$ & $\mathrm{Mg}$ & $\mathrm{S}$ \\
$\begin{array}{c}\text { Fertilizer } \\
\text { solution } \\
\text { one }\end{array}$ & 510 & 79 & 937 & 323 & 125 & 232 \\
$\begin{array}{c}\text { Fertilizer } \\
\quad 592\end{array}$ & 91 & 1202 & 430 & 125 & 241 \\
$\quad \begin{array}{l}\text { solution } \\
\text { two }\end{array}$ & & & & & & \\
\hline
\end{tabular}

using a modified version of the Australian Standards method for potting mixes (AS 3743-2003; appendix B) (Australian Standards International, 2003). The modification consisted in soaking the substrate material in water for a period of $5 \mathrm{~d}$ before measuring AFP and WHC to ensure thorough wetting, given the water repellence of the biochar. Wettability was determined using the WDPTT according to the method of Letey (1969). This method was modified in that substrates were not passed through a sieve before measurement as this would have altered the proportions of sawdust and biochar in the mixed substrates. To measure $\mathrm{pH}$ and EC, samples of all substrates were oven dried at $70{ }^{\circ} \mathrm{C}$ until a constant mass was obtained. Following this, $5 \mathrm{~g}$ of sample was added to $50 \mathrm{~mL}$ of deionized water and shaken for $30 \mathrm{~min}$ with an end-over-end shaker. The samples were then left in a refrigerator at $4{ }^{\circ} \mathrm{C}$ for $24 \mathrm{~h}$ and subsequently shaken on the end-over-end shaker for a further $30 \mathrm{~min}$. Samples were then filtered with Whatman no. 42, ashless filter paper, and $\mathrm{pH}$ and $\mathrm{EC}$ of the water extract were measured. The $\mathrm{pH}$ and EC of substrate samples were also measured after being leached with tap water to assess the effects that this would have on these properties following the same procedure as for the unleached samples.

Growth trial. One hundred tomato (cv. Alboran RZ, Rijk Zwann, NL) seeds were sown, germinated, and grown in "rockwool" 
starter cubes for $64 \mathrm{~d}$ in a climate-controlled greenhouse. A parallel study indicated that no chronic phytotoxicity, nutrient toxicity, or deficiency issues resulted from the use of biochar as a soilless substrate for the growth of young tomato seedlings (S.J. Dunlop and J.J. Wargent, unpublished data). After 64 d, 50 seedlings were selected and randomly transplanted into 11-L substrate modules containing one of five different substrates. The substrate modules were arranged in a reduced Latin square design with five rows, one module from each treatment per row and five replicates of each treatment in total. There were two plants per substrate module giving 10 plants per treatment in total. Planting density was $\approx 1.67$ plants $/ \mathrm{m}^{2}$.

Plants were grown in these modules for $110 \mathrm{~d}$ at which point they were destructively harvested. The number of fruit trusses per vine was not manipulated but all multiple trusses were pruned to a single fruit truss. All plants were pruned to a single leader but vines were not decapitated. Plants were grown using a standard run to waste hydroponic system. Fertigation (fertilizer and irrigation) was applied through a drip irrigation system using one $2 \mathrm{~L} \cdot \mathrm{h}^{-1}$ dripper per plant (two per substrate module). A two part stock nutrient solution was injected directly into fertigation system using two water powered nonelectric chemical injectors (DI 16; Dosatron International S. A., Bordeux, France). The EC of fertigation solution was monitored every few days and the chemical injector adjusted to maintain an EC of $2.2 \mathrm{mS} \cdot \mathrm{cm}^{-1}$ in the early stages of growth and an EC of 3.1-3.5 mS. $\mathrm{cm}^{-1}$ during the later stages. From $39 \mathrm{~d}$ after transplant until the end of the trial $\mathrm{pH}$ was managed by adding a third chemical injector (DI 16; Dosatron International S. A.), which injected a diluted orthophosphoric acid solution. The $\mathrm{pH}$ of fertigation solution was monitored every few days and the chemical injector adjusted to maintain $\mathrm{pH}$ at 5.4-6.0.

Plant measurements and analyses. The maximum length and width of the terminal leaflet of the third true leaf of each plant were measured every second day for the first $26 \mathrm{~d}$ after transplant. Stem diameter was measured flush with the rockwool starter cube at the same time. Plant height, from the top of the rockwool starter cube to the top of the main stem, was also measured. Relative growth rate (RGR) $\left(\mathrm{mm} \cdot \mathrm{mm}^{-1} \cdot \mathrm{d}^{-1}\right)$ for leaf length, leaf width, stem diameter, and plant height were calculated from this data for each period between measurements and as an average for the total period that measurements were taken. One young, fully expanded leaflet was harvested from the seventh leaf below the apical shoot of each plant $41 \mathrm{~d}$ after transplant. These leaves were oven dried at $60{ }^{\circ} \mathrm{C}$ until a constant mass was obtained. They were then ground using a sample mill and stored in a desiccator until nutrient content analysis was conducted. Kjeldahl digestion of leaf tissue samples was conducted. Subsequently, $\mathrm{N}$ and $\mathrm{P}$ content of the digest were determined by colorimetry using an autoanalyser (Technicon AutoAnalyzer II; Technicon Instruments Corporation, New York) following the alkaline phenol method for $\mathrm{N}$, and the vandomolybdate method for P (AOAC, 1975; Scheiner, 1976). Leaf tissue samples were also digested with concentrated nitric acid $(65 \%, A R)$ and potassium $(\mathrm{K})$, calcium $(\mathrm{Ca})$, magnesium $(\mathrm{Mg})$, iron $(\mathrm{Fe})$, and copper (Cu) content of the digest determined by AAS (Avanta $\Sigma$; GBC Scientific Equipment, Dandenong, Australia).

One hundred and ten days after seedlings were transplanted into the substrate modules, and after all red and green fruit had been removed, all plants were destructively harvested. Stem diameter was measured flush with the top of the rockwool starter block before harvesting. Plants were cut level with the top of the rockwool starter block and the length of the main vine stem was measured. Following this, fresh weight of all shoot material was determined. Root material could not be separated from the module blocks for mass quantification.

During the trial period, fruit was harvested individually on reaching the red stage of ripeness (i.e., $90 \%$ of the fruit surface was red in color). Fruit were weighed and fruit number was recorded. Immediately, before plants being destructively harvested, all fruit were harvested, weighed, and fruit number recorded. Fruit at the light red or red stage of ripeness, according to the U.S. Department of Agriculture fruit color classification, were recorded as ripe fruit, and all fruit not yet at the light red stage of ripeness were recorded as green fruit. Total soluble solids (TSS) content of the first ripe fruit harvested from each truss was measured with a refractometer (N-20; ATAGO Co., INC, Tokyo, Japan). When multiple fruit were harvested from a single truss at one time the TSS content of the fruit closest to the main stem end of the truss was measured. Incidence of blossom end rot (BER) and fruit deformities were recorded for all plants.

Substrate module analysis. Volumetric water content (VWC) of the substrate modules was measured four times during the last 3 weeks of the main growth trial using time domain reflectometry (TDR). Probes of $15 \mathrm{~cm}$ attached to a portable TDR instrument (Mini Trase; Soil Moisture Equipment Corp., Santa Barbara, CA) were inserted horizontally into the side of each substrate module at the horizontal and vertical midpoint and VWC recorded. Each time, VWC was measured once all substrate modules had ceased draining postfertigation. However, VWC was measured at different times of day and at varying intervals after fertigation. Substrate solution was extracted directly from the substrate modules on the day that seedlings were transplanted, and 7, 14, 21, 35, 69, and $110 \mathrm{~d}$ after transplant following a modified version of the method used by Komosa et al. (2009). The extraction was conducted using a $100-\mathrm{mL}$ syringe with a $100-\mathrm{mm}$ needle attached after all substrate modules had finished draining following fertigation. The syringe was inserted into the side of each module at four evenly spaced points along the vertical midpoint. About $5 \mathrm{~mL}$ was extracted at each point giving a complete extraction volume of $20 \mathrm{~mL}$ per substrate module. The $\mathrm{pH}$ and $\mathrm{EC}$ of this substrate module extract were measured. On two occasions during the trial (14 and $69 \mathrm{~d}$ after transplant) the solution extraction volume was increased to $60 \mathrm{~mL}$ per substrate module. About $35 \mathrm{~mL}$ of this extract was filtered by vacuum pump through a 0.45 -micron cellulose nitrate membrane filter and frozen until nutrient concentration analysis of the substrate solution was conducted. Concentration of $\mathrm{NO}_{3}-\mathrm{N}$, and dissolved inorganic $\mathrm{P}$ (DIP) was determined by colorimetry using autoanalysers following the automated hydrazine reduction method for $\mathrm{N}$ and the phosphomolybdate complex method for P (John, 1970; Keith, 1992; Murphy and Riley, 1962). K, Ca, Mg, and $\mathrm{Fe}$ were determined by AAS.

Statistical analysis. Analysis of variance and Tukey's multiple range test using Minitab 16 statistical software (Minitab Inc., PA) were used to determine significant differences between treatment groups at $P<0.05$.

\section{Results}

\section{Biochar characterization}

As indicated in Materials and Methods, the biochar used in this trial was produced from two batches and these were characterized separately before being mixed for its use as substrate. During the second run, the targeted temperature of $550{ }^{\circ} \mathrm{C}$ was not uniformly reached and a range of 440 to $550{ }^{\circ} \mathrm{C}$ was recorded within the twin retorts. In spite of this and with some exceptions, the physicochemical properties of the two batches were alike (Table 3 ), with a yield

Table 3. General physicochemical properties of the two batches of biochar produced from tomato crop green waste feedstock.

\begin{tabular}{|c|c|c|c|c|c|c|c|c|c|c|c|c|c|c|}
\hline \multirow[b]{2}{*}{ Material } & \multirow{2}{*}{$\begin{array}{c}\text { Biochar } \\
\text { yield }(\%)\end{array}$} & $\mathrm{C}_{\text {total }}$ & $\overline{\mathrm{C}_{\text {org }}}$ & $\mathrm{C}_{\text {inorg }}{ }^{\mathrm{z}}$ & $\overline{N_{\text {total }}}$ & $\mathrm{H}^{\mathrm{z}}$ & $\operatorname{Ash}^{1}$ & $\mathrm{H}^{\mathrm{z}} / \mathrm{C}_{\text {org }}$ & \multirow[b]{2}{*}{$\mathrm{pH}$} & \multirow[b]{2}{*}{$\mathrm{EC}\left(\mathrm{mS} \cdot \mathrm{cm}^{-1}\right)$} & \multirow[b]{2}{*}{ WDPT (s) } & \multirow[b]{2}{*}{$\operatorname{CEC~}\left(\mathrm{mmol}_{\mathrm{c}} \cdot \mathrm{kg}^{-1}\right)$} & $\mathrm{CaCO}_{3}$ eq. & $\overline{\text { FA-P }}$ \\
\hline & & & & $\left(\mathrm{g} \cdot \mathrm{kg}^{-1}\right)$ & & & & DW & & & & & \multicolumn{2}{|c|}{$\left(\mathrm{g} \cdot \mathrm{kg}^{-1}\right)$} \\
\hline$\overline{\text { Biochar } 1}$ & 37 & 550 & 546 & 3.9 & 16 & 2 & 22 & 0.53 & 10.41 & 3.31 & 7 & 523.9 & 141.79 & 14.51 \\
\hline Biochar 2 & 39 & 549 & n.a. & n.a. & 16 & n.a. & n.a. & n.a. & 10.39 & 3.03 & $>10,800$ & 469.4 & 116.00 & 13.35 \\
\hline
\end{tabular}

Biochar 1 = biochar first batch; Biochar $2=$ biochar second batch; $\mathrm{VM}=$ volatile matter; WDPT $=$ water drop penetration time test; CEC $=$ cation exchange capacity; $\mathrm{CaCO}_{3}$ eq = liming equivalence; FA-P = P extractable with $2 \%$ formic acid.

${ }^{2}$ Analyses carried out on a biochar produced in a laboratory kiln (as described in Calvelo Pereira et al., 2011) at a highest heating temperature of $550{ }^{\circ} \mathrm{C}$ as in the $2 \mathrm{~m}^{3}$ kiln due to lack of enough sample (biochar $\mathrm{C}$ and $\mathrm{N}$ content were alike with both kilns). 
defined as the mass ratio of biochar recorded after pyrolysis and that of the initial feedstock of $\approx 38 \%$, a $\mathrm{C}_{\text {total }}$ and $\mathrm{N}_{\text {total }}$ contents of $55 \%$ and $1.6 \%$, respectively, and a $\mathrm{pH} 10.4$. Slight differences were detected in EC (3.3 and $\left.3.0 \mathrm{mS} \cdot \mathrm{cm}^{-1}\right)$ and $\mathrm{CaCO}_{3}$ (142 and 116 $\mathrm{g} \cdot \mathrm{kg}^{-1}$ ) of the two batches, these values being always greater in the biochar from the first batch. The greatest difference detected among the two batches was the WDPT value, which was more than 1000 times smaller in the first batch as compared with the second batch.

\section{Substrate characterization}

Substrate physical properties. There were significant differences $(P<0.05)$ in the physical properties of the substrates depending on the proportion of sawdust and biochar they contained (Table 4). BD and AFP generally decreased as the proportion of biochar in the substrate mix increased; BD and AFP of the BC100-SD0 substrate were $9 \%$ and $14 \%$ less than the BC0-SD100 substrate, respectively. In contrast, WHC tended to increase as the proportion of biochar in the mix increased with the WHC of the $\mathrm{BC} 100$ SD0 substrate being $20 \%$ greater than the BC0-SD100 substrate. In terms of wettability, the $\mathrm{BC} 100-\mathrm{SD} 0$ substrate was considerably more water repellent than the BC0-SD100 substrate, with a WDPT 30-40 times greater. However, all of the substrates containing mixtures of biochar and sawdust were significantly $(P<0.05)$ less water repellent than either of these substrates.

Substrate chemical properties. There were significant differences $(P<0.05)$ and consistent trends in the chemical properties that were related to the proportion of sawdust or biochar in the substrate (Table 4). Before and after the substrates had been leached, all except the $0 \mathrm{BC}-100 \mathrm{SD}$ substrate had a $\mathrm{pH}>7$. Both the $\mathrm{pH}$ and $\mathrm{EC}$ of the substrates were greater as the proportion of biochar in the substrate increased. Leaching resulted in a reduction in $\mathrm{EC}$ and $\mathrm{pH}$ of all substrates, except the 0BC-100SD substrate, but the effect on $\mathrm{EC}$ was much greater. Although the EC of the 0BC-100SD substrate decreased in response to leaching, the $\mathrm{pH}$ actually increased from being acidic to almost neutral.

\section{Growth trial}

Plant growth. Average RGR over the total period that measurements were taken was $\approx 0.11 \mathrm{~mm} \cdot \mathrm{mm}^{-1} \cdot \mathrm{d}^{-1}$ to $0.15 \mathrm{~mm} \cdot \mathrm{mm}^{-1} \cdot \mathrm{d}^{-1}$ for leaf length, leaf width, and plant height, and $\approx 0.06 \mathrm{~mm} \cdot \mathrm{mm}^{-1} \cdot \mathrm{d}^{-1}$ for stem diameter (Table 5). For the parameters measured, there were no significant $(P<0.05)$ differences in RGR between plants grown in any of the substrates. This was the case for each of the periods between measurements, and the average for the total period that measurements were taken.

Leaf nutrient content. Leaf N, P, Ca, Fe, and $\mathrm{Cu}$ content did not differ significantly $(P<0.05)$ between plants grown in any of the substrates (Table 6). However, $\mathrm{K}$ and $\mathrm{Mg}$ contents were significantly higher $(P<0.05)$ in plants grown in the 100BC-0SD substrate compared with the 0BC-100SD substrate. In fact, there was a consistent trend of $\mathrm{Mg}$ levels increasing as the proportion of biochar in the substrate increased (Table 6). Despite some differences between treatments, the leaf nutrient content of all plants, except for $\mathrm{Ca}$, fell within the typical sufficiency range for tomato plants. The $\mathrm{Ca}$ content of leaves from plants grown in all substrates was above the sufficiency range.

Plant biomass production at harvest, fruit yield, and quality. Average total shoot fresh weight ranged between 1460 and $1533 \mathrm{~g}$ per plant, stem diameter varied from 13.5 to

$14 \mathrm{~mm}$, and vine stem length was between 254 and $261 \mathrm{~cm}$, there being no significant $(P<0.05)$ differences among treatments (Table 7). Average number of green fruit per plant ranged from 40 to 44 , average ripe fruit number from 23 to 28 , average green fruit yield per plant from 1952 and $2209 \mathrm{~g}$, and average ripe fruit yield from 4544 to $5028 \mathrm{~g}$ (Table 7), there being no significant $(P<0.05)$ differences between treatments in terms of green fruit and ripe fruit number, or green fruit and ripe fruit yield. The TSS content of ripe fruit and occurrence of BER and fruit deformities were measured as

Table 4. Mean bulk Density (BD), air-filled porosity (AFP), water-holding capacity (WHC), and water drop penetration time (WDPT) of substrates consisting of various mixtures of pine sawdust, and tomato crop green-waste biochar. All substrate mixtures were soaked in water for a period of $5 \mathrm{~d}$ before measuring BD, AFP, and WHC to overcome the water repellence of the biochar. Mean $\mathrm{pH}$ and $\mathrm{EC}$ of substrates consisting of various mixtures of pine sawdust (SD), and tomato crop green-waste biochar (BC). The $\mathrm{pH}$ and $\mathrm{EC}$ of the raw substrates were measured (before leaching). The $\mathrm{pH}$ and EC of the substrates were also measured after they were pretreated by leaching with tap water repeatedly over a 3 -d period (after leaching).

\begin{tabular}{|c|c|c|c|c|c|c|c|c|}
\hline \multirow[b]{3}{*}{ Substrate $^{z}$} & \multirow[b]{3}{*}{$\mathrm{BD}\left(\mathrm{g} \mathrm{cm}^{-3}\right)$} & \multirow[b]{3}{*}{ AFP $(\%)$} & \multirow[b]{3}{*}{ WHC (\%) } & \multirow[b]{3}{*}{ WDPT (s) } & \multirow[b]{2}{*}{$\mathrm{pH}$} & $\overline{\mathrm{EC}}$ & \multirow[b]{2}{*}{$\mathrm{pH}$} & \multirow{2}{*}{$\frac{\mathrm{EC}}{\left(\mathrm{mS} \cdot \mathrm{cm}^{-1}\right)}$} \\
\hline & & & & & & $\left(\mathrm{mS} \cdot \mathrm{cm}^{-1}\right)$ & & \\
\hline & & & & & \multicolumn{2}{|c|}{ Before leaching } & \multicolumn{2}{|c|}{ After leaching } \\
\hline$\overline{\text { OBC-100SD }}$ & $0.140 \mathrm{a}$ & $42 a$ & $45 \mathrm{a}$ & $58 \mathrm{~b}$ & $5.21 \mathrm{a}^{\mathrm{y}}$ & $0.1 \mathrm{a}$ & $6.96 \mathrm{a}$ & $0.04 \mathrm{a}$ \\
\hline $25 \mathrm{BC}-75 \mathrm{SD}$ & $0.134 \mathrm{~b}$ & $42 \mathrm{a}$ & $45 \mathrm{a}$ & $4 \mathrm{a}$ & $9.25 \mathrm{~b}$ & $4.6 \mathrm{~b}$ & $7.47 \mathrm{~b}$ & $0.08 \mathrm{~b}$ \\
\hline $50 \mathrm{BC}-50 \mathrm{SD}$ & $0.129 \mathrm{bc}$ & $39 a$ & $47 \mathrm{a}$ & $1 \mathrm{a}$ & $10.48 \mathrm{c}$ & $10.0 \mathrm{c}$ & $7.76 \mathrm{c}$ & $0.12 \mathrm{c}$ \\
\hline $75 \mathrm{BC}-25 \mathrm{SD}$ & $0.133 \mathrm{bc}$ & $33 \mathrm{~b}$ & $53 \mathrm{~b}$ & $2 \mathrm{a}$ & $10.55 \mathrm{~cd}$ & $15.9 \mathrm{~d}$ & $8.29 \mathrm{~d}$ & $0.17 \mathrm{~d}$ \\
\hline 100BC-0SD & $0.128 \mathrm{c}$ & $28 \mathrm{c}$ & $54 \mathrm{~b}$ & $1800 \leq 2400 \mathrm{c}$ & $10.61 \mathrm{~d}$ & $21.2 \mathrm{e}$ & $9.32 \mathrm{e}$ & $0.35 \mathrm{e}$ \\
\hline
\end{tabular}

zThe number preceding BC or SD in the substrate description indicates percentage of BC or SD the substrate contains on a dry weight basis.

${ }^{\mathrm{y}} \mathrm{Means}$ in the same column that share a letter are not significantly different at the $5 \%$ level according to Tukey's multiple range test.

Table 5. Mean relative growth (RGR) rate for leaf length, leaf width, stem diameter and plant height of tomato cv. Alboran RZ plants grown in substrates consisting of various mixtures of pine sawdust (SD) and tomato crop green-waste biochar (BC). Leaf length, leaf width, stem diameter, and plant height were measured every second day for the first $26 \mathrm{~d}$ after transplant. The average RGR for this period has been used as there were no significant differences in RGR at any point within this period.

\begin{tabular}{lcccr}
\hline & \multicolumn{4}{c}{ Relative growth rate } \\
\cline { 2 - 5 } Substrate $^{\mathrm{z}}$ & Leaf length & Leaf width & Stem diam & Plant ht \\
\cline { 2 - 5 } 0BC-100SD & $0.14 \mathrm{a}^{\mathrm{y}}$ & $0.13 \mathrm{a}$ & $0.05 \mathrm{a}$ & $0.14 \mathrm{a}$ \\
25BC-75SD & $0.13 \mathrm{a}$ & $0.14 \mathrm{a}$ & $0.06 \mathrm{a}$ & $0.14 \mathrm{a}$ \\
50BC-50SD & $0.12 \mathrm{a}$ & $0.14 \mathrm{a}$ & $0.06 \mathrm{a}$ & $0.13 \mathrm{a}$ \\
75BC-25SD & $0.12 \mathrm{a}$ & $0.15 \mathrm{a}$ & $0.06 \mathrm{a}$ & $0.13 \mathrm{a}$ \\
100BC-0SD & $0.11 \mathrm{a}$ & $0.11 \mathrm{a}$ & $0.06 \mathrm{a}$ & $0.14 \mathrm{a}$ \\
\hline
\end{tabular}

${ }^{\mathrm{z}}$ The number preceding $\mathrm{BC}$ or SD in the substrate description indicates percentage of biochar (BC) or sawdust (SD) the substrate contains on a dry weight basis.

${ }^{y}$ Means in the same column that share a letter are not significantly different at the $5 \%$ level according to Tukey's multiple range test.

Table 6. Mean leaf nutrient content of tomato cv. Alboran RZ plants grown in substrates consisting of various mixtures of pine sawdust (SD) and tomato crop green-waste biochar (BC). Leaves used for nutrient analysis were harvested $41 \mathrm{~d}$ after transplant.

\begin{tabular}{|c|c|c|c|c|c|c|c|}
\hline \multirow[b]{2}{*}{ Substrate $^{z}$} & $\mathrm{~N}$ & $\mathrm{P}$ & $\mathrm{K}$ & $\mathrm{Ca}$ & $\mathrm{Mg}$ & $\mathrm{Fe}$ & $\mathrm{Cu}$ \\
\hline & \multicolumn{5}{|c|}{$\left(\mathrm{g} \cdot \mathrm{kg}^{-1}\right)$} & \multicolumn{2}{|c|}{$\left(\mathrm{mg} \cdot \mathrm{kg}^{-1}\right)$} \\
\hline$\overline{0 B C-100 S D}$ & $4.54 \mathrm{a}^{\mathrm{y}}$ & $0.56 \mathrm{a}$ & $3.28 \mathrm{~b}$ & $3.73 \mathrm{a}$ & $0.43 \mathrm{~d}$ & $169 \mathrm{a}$ & $13.6 \mathrm{a}$ \\
\hline $25 \mathrm{BC}-75 \mathrm{SD}$ & $4.50 \mathrm{a}$ & $0.56 \mathrm{a}$ & $3.37 \mathrm{ab}$ & $3.97 \mathrm{a}$ & $0.49 \mathrm{c}$ & $193 \mathrm{a}$ & $13.4 \mathrm{a}$ \\
\hline 50BC-50SD & $4.59 \mathrm{a}$ & $0.61 \mathrm{a}$ & $3.37 \mathrm{ab}$ & $4.06 \mathrm{a}$ & $0.54 \mathrm{bc}$ & $174 \mathrm{a}$ & $13.3 \mathrm{a}$ \\
\hline $75 \mathrm{BC}-25 \mathrm{SD}$ & $4.54 \mathrm{a}$ & $0.58 \mathrm{a}$ & $3.47 \mathrm{ab}$ & $3.99 \mathrm{a}$ & $0.58 \mathrm{ab}$ & $172 \mathrm{a}$ & $13.3 \mathrm{a}$ \\
\hline 100BC-0SD & $4.58 \mathrm{a}$ & $0.57 \mathrm{a}$ & $3.64 \mathrm{a}$ & $3.76 \mathrm{a}$ & $0.63 \mathrm{a}$ & $178 \mathrm{a}$ & $13.5 \mathrm{a}$ \\
\hline Sufficiency range ${ }^{x}$ & $35-50$ & $3.0-6.5$ & $28-45$ & $10-30$ & $3.5-10$ & $50-300$ & $5-35$ \\
\hline
\end{tabular}

${ }^{\mathrm{z}}$ The number preceding $\mathrm{BC}$ or SD in the substrate description indicates percentage of BC or SD the substrate contains on a dry weight basis.

${ }^{y}$ Means in the same column that share a letter are not significantly different at the $5 \%$ level according to Tukey's multiple range test.

${ }^{x}$ Sufficiency range for greenhouse tomatoes (NCDA\&CS, 2011). 
Table 7. Mean shoot fresh weight, stem diameter, stem length, mean green fruit number, ripe fruit number, green fruit yield, ripe fruit yield, mean total soluble solids (TSS) content of ripe fruit, number of fruit affected by blossom end rot (BER), and number of fruit displaying deformed development for of tomato cv. Alboran RZ plants grown in substrates consisting of various mixtures of pine sawdust (SD) and tomato crop green-waste biochar (BC). Plants were destructively harvested $110 \mathrm{~d}$ after transplant. Shoot fresh weight includes all aerial parts of plants except fruit. Stem length is the length of the central tomato vine stem. All fruit picked at the full red stage of ripeness during the growth trial, and all fruit at the light red or red stage of ripeness immediately before being destructively harvested were recorded as ripe fruit. All fruit not yet at the light red stage of ripeness when plants were destructively harvested were recorded as green fruit.

\begin{tabular}{|c|c|c|c|c|c|c|c|c|c|c|}
\hline \multirow[b]{2}{*}{ Substrate $^{z}$} & \multirow{2}{*}{$\frac{\text { Shoot fresh wt }}{(\mathrm{g})}$} & \multirow{2}{*}{$\frac{\text { Stem diam }}{(\mathrm{mm})}$} & \multirow{2}{*}{$\frac{\text { Stem length }}{(\mathrm{cm})}$} & \multicolumn{2}{|c|}{ Fruit number } & \multicolumn{2}{|c|}{ Fruit yield (g) } & \multirow{2}{*}{$\begin{array}{l}\text { TSS content } \\
\left({ }^{\circ} \text { Brix }\right)\end{array}$} & \multirow{2}{*}{$\begin{array}{c}\text { BER } \\
\text { Fruit no. }\end{array}$} & \multirow{2}{*}{$\begin{array}{c}\text { Fruit deformities } \\
\text { Fruit no. }\end{array}$} \\
\hline & & & & Green fruit & Ripe fruit & Green fruit & Ripe fruit & & & \\
\hline$\overline{0 B C-100 S D}$ & $1460 \mathrm{a}^{\mathrm{y}}$ & $13.7 \mathrm{a}$ & $254 \mathrm{a}$ & $44 \mathrm{a}$ & $24 \mathrm{a}$ & $2209 a$ & $4666 \mathrm{a}$ & $5.1 \mathrm{a}$ & $0.1 \mathrm{~b}$ & $1.0 \mathrm{a}$ \\
\hline 25BC-75SD & $1533 \mathrm{a}$ & $14.0 \mathrm{a}$ & $261 \mathrm{a}$ & $44 \mathrm{a}$ & $26 \mathrm{a}$ & $2114 \mathrm{a}$ & $4686 \mathrm{a}$ & $5.1 \mathrm{a}$ & $0.3 \mathrm{ab}$ & $0.3 \mathrm{a}$ \\
\hline 50BC-50SD & $1511 \mathrm{a}$ & $13.5 \mathrm{a}$ & $255 \mathrm{a}$ & $40 \mathrm{a}$ & $23 \mathrm{a}$ & $2085 \mathrm{a}$ & $4544 \mathrm{a}$ & $5.1 \mathrm{a}$ & $1.3 \mathrm{a}$ & $0.7 \mathrm{a}$ \\
\hline 75BC-25SD & $1511 \mathrm{a}$ & $13.5 \mathrm{a}$ & $257 \mathrm{a}$ & $40 \mathrm{a}$ & $26 \mathrm{a}$ & $1952 \mathrm{a}$ & $4878 \mathrm{a}$ & $5.1 \mathrm{a}$ & $0.3 \mathrm{ab}$ & $0.9 \mathrm{a}$ \\
\hline 100BC-0SD & $1523 \mathrm{a}$ & $13.7 \mathrm{a}$ & $259 \mathrm{a}$ & $40 \mathrm{a}$ & $28 \mathrm{a}$ & $2051 \mathrm{a}$ & $5028 \mathrm{a}$ & $5.0 \mathrm{a}$ & $0.4 \mathrm{ab}$ & $0.4 \mathrm{a}$ \\
\hline
\end{tabular}

${ }^{\mathrm{z}}$ The number preceding BC or SD in the substrate description indicates percentage of biochar.

${ }^{y}$ Means in the same column that share a letter are not significantly different at the $5 \%$ level according to Tukey's multiple range test.

indicators of fruit quality. Average TSS content of ripe fruit was $\approx 5.0-5.1^{\circ} \mathrm{Brix}$ and did not vary significantly $(P<0.05)$ between treatments (Table 7). There were some incidences of BER and other fruit deformities, though they were generally limited to less than one affected fruit per plant. However, there was no relationship between the proportion of biochar in the substrate and the frequency that these conditions occurred.

\section{Substrate module analysis}

Substrate module VWC. At 89 and $106 \mathrm{~d}$ after seedlings were transplanted into the substrate modules VWC ranged from $40 \%$ to $60 \%$ and was significantly $(P<0.05)$ higher in the 100BC-0SD substrate compared with the 0BC-100SD substrate (Table 8). However, on both occasions, VWC of these substrates did not differ from any of the other substrates. This was also the case for the average VWC over the period that measurements were taken, which was $\approx 39 \%$ to $49 \%$ depending on substrate. At 102 and $110 \mathrm{~d}$ after transplant, VWC did not vary significantly $(P<0.05)$ between any of the substrates (Table 8). At $102 \mathrm{~d}$ after transplant, VWC was $\approx 13 \%$ to $17 \%$, which was very low relative to the other days measurements were taken.

Substrate module solution $\mathrm{pH}$. As expected, there was a strong trend indicating that the $\mathrm{pH}$ of substrate solution was higher in the substrates containing greater proportions of biochar (Table 9). Throughout the production period, the $\mathrm{pH}$ of the substrate solution in the 100BC-0SD modules was significantly $(P<0.05)$ higher than in the 0BC-100SD modules. On the day of transplant, the $\mathrm{pH}$ of the solution in the 100BCOSD modules was 10.6 compared with 6.5 in the 0BC-100SD substrate. However, overtime, the difference in $\mathrm{pH}$ between substrates was reduced, and by $110 \mathrm{~d}$ after transplant the $\mathrm{pH}$ of the solution in the 100BC-0SD and 0BC-100SD substrates was 6.8 and 6.2, respectively (Table 9). Overall, the $\mathrm{pH}$ of substrate solution in all modules decreased, but in the first $14 \mathrm{~d}$ after transplant the $\mathrm{pH}$ of the solution in the 25BC-75SD and 0BC100SD substrates slightly increased (from 7.6 to 7.9 , and 6.5 to 7.8 , respectively). From this point onwards, the $\mathrm{pH}$ of the solution in these substrates decreased. Generally, the $\mathrm{pH}$ of

Table 8. Mean volumetric water content (VWC, \%) of substrate modules containing various mixtures of pine sawdust (SD) and tomato crop green-waste biochar (BC), during tomato cv. Alboran RZ crop production. VWC was measured using a portable TDR instrument 89, 102, 106, and $110 \mathrm{~d}$ after seedlings were transplanted into substrate modules.

\begin{tabular}{llcccc}
\hline Substrate $^{\mathrm{z}}$ & Day 89 & Day 102 & Day 106 & Day 110 & Avg \\
\hline 0BC-100SD & $40.6 \mathrm{~b}^{\mathrm{y}}$ & $13.3 \mathrm{a}$ & $41.7 \mathrm{~b}$ & $58.9 \mathrm{a}$ & $38.6 \mathrm{~b}$ \\
25BC-75SD & $47.0 \mathrm{ab}$ & $17.1 \mathrm{a}$ & $45.7 \mathrm{ab}$ & $60.0 \mathrm{a}$ & $42.5 \mathrm{ab}$ \\
50BC-50SD & $47.1 \mathrm{ab}$ & $15.8 \mathrm{a}$ & $48.4 \mathrm{ab}$ & $59.1 \mathrm{a}$ & $42.6 \mathrm{ab}$ \\
75BC-25SD & $46.8 \mathrm{ab}$ & $15.9 \mathrm{a}$ & $46.5 \mathrm{ab}$ & $61.7 \mathrm{a}$ & $42.7 \mathrm{ab}$ \\
100BC-0SD & $56.6 \mathrm{a}$ & $17.1 \mathrm{a}$ & $57.9 \mathrm{a}$ & $63.2 \mathrm{a}$ & $48.7 \mathrm{a}$ \\
\hline
\end{tabular}

${ }^{\mathrm{z} T h e}$ number preceding $\mathrm{BC}$ or $\mathrm{SD}$ in the substrate description indicates percentage of $\mathrm{BC}$ or SD the substrate contains on a dry weight basis.

${ }^{\mathrm{y}}$ Means in the same column that share a letter are not significantly different at the $5 \%$ level according to Tukey's multiple range test.

Table 9. The $\mathrm{pH}$ of fertigation solution (fert. solution) and solution extracted from substrate modules containing various mixtures of pine sawdust (SD) and tomato crop green-waste biochar (BC), during tomato cv. Alboran RZ crop production. Substrate solution was extracted from the substrate modules on the day seedlings were transplanted, and 7, 14, 21, 35, 69, and $110 \mathrm{~d}$ after transplant.

\begin{tabular}{lcclllll}
\hline Substrate $^{\mathrm{z}}$ & Day 0 & Day 7 & Day 14 & Day 21 & Day 35 & Day 69 & Day 110 \\
\hline 0BC-100SD & $6.53 \mathrm{e}^{\mathrm{y}}$ & $7.53 \mathrm{e}$ & $7.76 \mathrm{~d}$ & $7.71 \mathrm{~d}$ & $7.41 \mathrm{~cd}$ & $6.54 \mathrm{c}$ & $6.15 \mathrm{~b}$ \\
25BC-75SD & $7.59 \mathrm{~d}$ & $7.81 \mathrm{~d}$ & $7.88 \mathrm{~cd}$ & $7.86 \mathrm{~d}$ & $7.67 \mathrm{c}$ & $6.72 \mathrm{c}$ & $6.16 \mathrm{~b}$ \\
50BC-50SD & $8.21 \mathrm{c}$ & $8.16 \mathrm{c}$ & $8.09 \mathrm{c}$ & $8.05 \mathrm{c}$ & $7.71 \mathrm{c}$ & $6.81 \mathrm{bc}$ & $6.21 \mathrm{~b}$ \\
75BC-25SD & $9.39 \mathrm{~b}$ & $8.86 \mathrm{~b}$ & $8.60 \mathrm{~b}$ & $8.52 \mathrm{~b}$ & $8.13 \mathrm{~b}$ & $7.02 \mathrm{~b}$ & $6.55 \mathrm{a}$ \\
100BC-0SD & $10.58 \mathrm{a}$ & $10.45 \mathrm{a}$ & $9.87 \mathrm{a}$ & $9.85 \mathrm{a}$ & $8.75 \mathrm{a}$ & $7.54 \mathrm{a}$ & $6.79 \mathrm{a}$ \\
Fert. solution & $7.27 \mathrm{~d}$ & $7.14 \mathrm{f}$ & $7.27 \mathrm{e}$ & $6.85 \mathrm{e}$ & $7.25 \mathrm{~d}$ & $6.02 \mathrm{~d}$ & $5.62 \mathrm{c}$ \\
\hline
\end{tabular}

${ }^{\mathrm{z} T h e}$ number preceding $\mathrm{BC}$ or SD in the substrate description indicates percentage of BC or SD the substrate contains on a dry weight basis.

${ }^{\mathrm{y}}$ Means in the same column that share a letter are not significantly different at the $5 \%$ level according to Tukey's multiple range test.

solution extracted from all substrates was higher than the $\mathrm{pH}$ of the fertigation solution throughout the growth period. The only exception being the solution from the $0 \mathrm{BC}$ 100SD substrate on the day seedlings were transplanted.

Substrate module solution EC. For the majority of the growth period, there was a trend indicating that substrate solution EC increased in substrates containing greater proportions of biochar (Table 10). From day 7 to 69 after transplant, the EC of the substrate solution in the 100BC-0SD modules was significantly $(P<0.05)$ higher than that in the 0BC-100SD modules. Seven days after transplant, the EC of the substrate solution in the 100BC-0SD modules was $3.4 \mathrm{mS} \cdot \mathrm{cm}^{-1}$ compared with $1.7 \mathrm{mS} \cdot \mathrm{cm}^{-1}$ in the $0 \mathrm{BC}$ 100SD modules. This difference had reduced by $69 \mathrm{~d}$ after transplant, at which point the EC of the solution in the 100BC-0SD and 0BC100SD substrates was 3.6 and $2.9 \mathrm{mS} \cdot \mathrm{cm}^{-1}$, respectively. The EC of the solution extracted from the 100BC-0SD modules was also significantly $(P<0.05)$ higher than the EC of the fertigation solution on a number of occasions (Table 10). The EC of solution extracted from all other substrates was lower, or did not differ significantly $(P<0.05)$, from that of the fertigation solution on all occasions except $14 \mathrm{~d}$ after transplant.

Substrate module of solution available nutrient content. Soluble nutrient content of solution extracted from the substrate modules was measured $14 \mathrm{~d}$ after transplant. At this time, there were significant $(P<0.05)$ differences in the concentration of individual nutrients in solution extracted from each of the substrates (Table 11). Levels of $\mathrm{NO}_{3}-\mathrm{N}$ and $\mathrm{K}$ tended to increase as the proportion of biochar contained in the substrates increased. Average $\mathrm{NO}_{3}-\mathrm{N}$ concentration was two times, and $\mathrm{K}$ concentration was almost three times higher in solution from the 100BC-0SD substrate compared with the 0BC-100SD substrate. $\mathrm{Mg}$ concentration was between 
23.2 and $66.3 \mu \mathrm{g} \cdot \mathrm{mL}^{-1}$, depending on the substrate, and also tended to increase as the proportion of biochar in the substrate increased, though the concentration in the 100BC-0SD substrate was amongst the lowest. Fe concentration was nearly 600 times higher in solution extracted from the $0 \mathrm{BC}$ 100 SD compared with the 100BC-0SD substrate, and was significantly higher $(P<0.05)$ in the 0BC-100SD substrate compared with all substrates containing biochar. Ca concentration ranged from 20.5 to $97.9 \mu \mathrm{g} \cdot \mathrm{mL}^{-1}$, depending on substrate, and there were significant $(P<0.05)$ differences between substrates (Table 11). However, there were no consistent trends relating this difference to the proportion of biochar in the substrate. Though there were no significant $(P<0.05)$ differences between substrates, average DIP concentration was 6.2 times higher in the 100BC-0SD compared with the 0BC-100SD and there was a consistent trend of mean DIP concentration increasing with increasing proportions of biochar in the substrate.

There were a number of significant $(P<$ 0.05 ) differences between the soluble nutrient content of the fertigation solution and the solution extracted from the various substrates (Table 11). $\mathrm{NO}_{3}-\mathrm{N}$ concentration was significantly $(P<0.05)$ lower in the 25BC-75SD and $0 \mathrm{BC}-100 \mathrm{SD}$ substrates and $\mathrm{K}$ concentration was higher in the 75BC-25SD and 100BC-0SD substrates relative to the fertigation solution. $\mathrm{Ca}$ concentration of the fertigation solution was significantly $(P<$ 0.05 ) higher than the solution extracted from all substrates, but $\mathrm{Mg}$ concentration of the fertigation solution was significantly $(P<$ $0.05)$ lower than solution from the $75 \mathrm{BC}$ 25SD and 50BC-50SD substrates. Fe concentration of the fertigation solution was significantly $(P<0.05)$ higher than solution from all except the 0BC-100SD substrate (Table 11). There were no significant differences $(P<0.05)$ in the DIP concentration of the fertigation solution and solution extracted from any of the substrates.

Soluble nutrient content of solution extracted from the substrate modules was again measured $69 \mathrm{~d}$ after transplant. Significant differences $(P<0.05)$ between the substrates also existed at this time (Table 12). $\mathrm{NO}_{3}-\mathrm{N}$ concentration of solution was significantly $(P<0.05)$ higher in the 100BC-0SD substrate compared with all other substrates, except the 75BC-25SD modules, and was $43 \%$ higher than the 0BC-100SD substrate. Fe concentration was at least twice as high in the 0BC-100SD substrate compared with all other substrates. DIP, which was more than two times higher in the 0BC-100SD substrate compared with the 100BC-0SD substrate, decreased as the proportion of biochar in the substrates increased. $\mathrm{Mg}$ concentration was almost $80 \%$ higher in the 100BC-0SD substrate compared with the 50BC-50SD, but $\mathrm{Mg}$ concentration in these substrates did not vary significantly $(P<0.05)$ from any other substrate (Table 12). There was no significant difference $(P<0.05)$ in either $\mathrm{Ca}$ or $\mathrm{K}$ concentrations amongst the substrates.

Table 10. The EC of fertigation solution (fert. solution) and solution extracted from substrate modules containing various mixtures of pine sawdust (SD) and tomato crop green-waste biochar (BC), during tomato cv. Alboran RZ crop production. Substrate solution was extracted from the substrate modules on the day seedlings were transplanted, and 7, 14, 21, 35, 69, and $110 \mathrm{~d}$ after transplant.

\begin{tabular}{llllllll}
\hline Substrate $^{z}$ & Day 0 & Day 7 & Day 14 & Day 21 & Day 35 & Day 69 & Day 110 \\
\hline 0BC-100SD & $1.77 \mathrm{a}^{\mathrm{y}}$ & $1.72 \mathrm{e}$ & $1.99 \mathrm{c}$ & $2.03 \mathrm{~d}$ & $0.87 \mathrm{~d}$ & $2.86 \mathrm{~b}$ & $4.63 \mathrm{ab}$ \\
25BC-75SD & $1.78 \mathrm{a}$ & $2.15 \mathrm{de}$ & $2.33 \mathrm{bc}$ & $2.43 \mathrm{c}$ & $1.14 \mathrm{~cd}$ & $2.90 \mathrm{~b}$ & $4.53 \mathrm{ab}$ \\
50BC-50SD & $1.98 \mathrm{a}$ & $2.49 \mathrm{~cd}$ & $2.58 \mathrm{ab}$ & $2.64 \mathrm{abc}$ & $1.33 \mathrm{c}$ & $2.98 \mathrm{~b}$ & $4.51 \mathrm{ab}$ \\
75BC-25SD & $2.22 \mathrm{a}$ & $3.05 \mathrm{ab}$ & $2.82 \mathrm{a}$ & $2.83 \mathrm{ab}$ & $1.86 \mathrm{~b}$ & $3.19 \mathrm{ab}$ & $5.03 \mathrm{ab}$ \\
100BC-0SD & $2.39 \mathrm{a}$ & $3.43 \mathrm{a}$ & $2.89 \mathrm{a}$ & $2.98 \mathrm{a}$ & $2.55 \mathrm{a}$ & $3.60 \mathrm{a}$ & $5.28 \mathrm{a}$ \\
Fert. solution & $2.47 \mathrm{a}$ & $2.71 \mathrm{bc}$ & $2.12 \mathrm{c}$ & $2.52 \mathrm{bc}$ & $2.44 \mathrm{a}$ & $3.30 \mathrm{ab}$ & $3.42 \mathrm{~b}$ \\
\hline
\end{tabular}

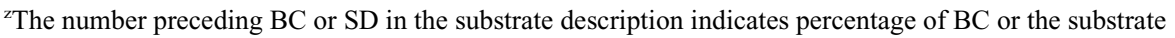
contains on a dry weight basis.

${ }^{y}$ Means in the same column that share a letter are not significantly different at the $5 \%$ level according to Tukey's multiple range test.

Table 11. Nitrate-nitrogen $\left(\mathrm{NO}_{3}-\mathrm{N}\right)$, dissolved inorganic phosphorous (DIP), potassium (K), calcium (Ca), magnesium $(\mathrm{Mg})$, and iron $(\mathrm{Fe})$ concentrations in fertigation solution (fert. solution) and solution extracted from substrate modules containing various mixtures of pine sawdust (SD) and tomato crop green-waste biochar (BC), during tomato cv. Alboran RZ crop production. Substrate solution was extracted $14 \mathrm{~d}$ after seedlings were transplanted into the substrate modules.

\begin{tabular}{lcccccr}
\hline & \multicolumn{5}{c}{ Nutrient concn $\left(\mu \mathrm{g} \cdot \mathrm{mL}^{-1}\right)$} \\
\cline { 2 - 7 } Substrate $^{\mathrm{z}}$ & $\mathrm{NO}_{3}-\mathrm{N}$ & $\mathrm{DIP}$ & $\mathrm{K}$ & $\mathrm{Ca}$ & $\mathrm{Mg}$ & $\mathrm{Fe}$ \\
\hline 0BC-100SD & $92 \mathrm{c}^{\mathrm{y}}$ & $0.5 \mathrm{a}$ & $281 \mathrm{c}$ & $82.3 \mathrm{bc}$ & $23.2 \mathrm{c}$ & $0.1696 \mathrm{~b}$ \\
25BC-75SD & $126 \mathrm{bc}$ & $0.9 \mathrm{a}$ & $323 \mathrm{c}$ & $82.4 \mathrm{bc}$ & $36.5 \mathrm{bc}$ & $0.0050 \mathrm{a}$ \\
50BC-50SD & $185 \mathrm{ab}$ & $1.1 \mathrm{a}$ & $384 \mathrm{c}$ & $97.9 \mathrm{c}$ & $55.8 \mathrm{ab}$ & $0.0058 \mathrm{a}$ \\
75BC-25SD & $171 \mathrm{ab}$ & $3.4 \mathrm{a}$ & $588 \mathrm{~b}$ & $42.3 \mathrm{ab}$ & $66.3 \mathrm{a}$ & $0.0042 \mathrm{a}$ \\
100BC-0SD & $197 \mathrm{a}$ & $3.1 \mathrm{a}$ & $762 \mathrm{a}$ & $20.5 \mathrm{a}$ & $36.5 \mathrm{bc}$ & $0.0003 \mathrm{a}$ \\
Fert. solution & $209 \mathrm{a}$ & $3.7 \mathrm{a}$ & $222 \mathrm{c}$ & $183.0 \mathrm{~d}$ & $14.3 \mathrm{c}$ & $0.7133 \mathrm{~b}$ \\
\hline
\end{tabular}

${ }^{z}$ The number preceding $\mathrm{BC}$ or SD in the substrate description indicates percentage of biochar (BC) or sawdust (SD) the substrate contains on a dry weight basis.

${ }^{y}$ Means in the same column that share a letter are not significantly different at the $5 \%$ level according to Tukey's multiple range test.

Table 12. Nitrate-nitrogen $\left(\mathrm{NO}_{3}-\mathrm{N}\right)$, dissolved inorganic phosphorous (DIP), potassium (K), calcium (Ca), magnesium $(\mathrm{Mg})$, and iron $(\mathrm{Fe})$ concentrations in fertigation solution (fert. solution) and solution extracted from substrate modules containing various mixtures of pine sawdust (SD) and tomato crop green-waste biochar (BC), during tomato cv. Alboran RZ crop production. Substrate solution was extracted $69 \mathrm{~d}$ after seedlings were transplanted into the substrate modules.

\begin{tabular}{llllllr}
\hline & \multicolumn{5}{c}{ Nutrient concn $\left(\mu \mathrm{g} \cdot \mathrm{mL}^{-1}\right)$} \\
\cline { 2 - 6 } Substrate $^{z}$ & $\mathrm{NO}_{3}-\mathrm{N}$ & $\mathrm{DIP}$ & $\mathrm{K}$ & $\mathrm{Ca}$ & $\mathrm{Mg}$ & $\mathrm{Fe}$ \\
\hline 0BC-100SD & $173 \mathrm{~b}^{\mathrm{y}}$ & $41 \mathrm{c}$ & $355 \mathrm{a}$ & $174 \mathrm{a}$ & $51 \mathrm{ab}$ & $0.805 \mathrm{bc}$ \\
25BC-75SD & $192 \mathrm{~b}$ & $33 \mathrm{bc}$ & $374 \mathrm{a}$ & $179 \mathrm{a}$ & $52 \mathrm{ab}$ & $0.409 \mathrm{ab}$ \\
$50 \mathrm{BC}-50 \mathrm{SD}$ & $190 \mathrm{~b}$ & $27 \mathrm{ab}$ & $334 \mathrm{a}$ & $161 \mathrm{a}$ & $46 \mathrm{~b}$ & $0.324 \mathrm{ab}$ \\
75BC-25SD & $213 \mathrm{ab}$ & $26 \mathrm{ab}$ & $412 \mathrm{a}$ & $192 \mathrm{a}$ & $64 \mathrm{ab}$ & $0.268 \mathrm{ab}$ \\
100BC-0SD & $248 \mathrm{a}$ & $16 \mathrm{a}$ & $459 \mathrm{a}$ & $190 \mathrm{a}$ & $83 \mathrm{a}$ & $0.216 \mathrm{a}$ \\
Fert. solution & $255 \mathrm{a}$ & $63 \mathrm{~d}$ & $404 \mathrm{a}$ & $173 \mathrm{a}$ & $47 \mathrm{ab}$ & $1.313 \mathrm{c}$ \\
\hline
\end{tabular}

${ }^{\mathrm{z}}$ The number preceding $\mathrm{BC}$ or SD in the substrate description indicates percentage of biochar (BC) or sawdust (SD) the substrate contains on a dry weight basis.

${ }^{y}$ Means in the same column that share a letter are not significantly different at the $5 \%$ level according to Tukey's multiple range test.

There were significant $(P<0.05)$ differences between the soluble nutrient content of the fertigation solution and the solution extracted from the various substrates $69 \mathrm{~d}$ after transplant (Table 12). $\mathrm{NO}_{3}-\mathrm{N}$ concentration was significantly $(P<0.05)$ higher in the fertigation solution compared with all substrates except the 100BC-0SD and 75BC-25SD modules. Fe concentration was significantly $(P<0.05)$ higher in the fertigation solution relative to all substrates except the 0BC-100SD modules. DIP concentration was at least $54 \%$ higher in the fertigation solution compared with all substrates. $\mathrm{K}, \mathrm{Ca}$, and $\mathrm{Mg}$ concentrations did not differ significantly $(P<0.05)$ between the fertigation solution and any of the substrates.

The concentrations of individual soluble nutrients contained in the substrate solution and the fertigation solution obtained on the 14th $\mathrm{d}$ after transplant differed from that obtained $69 \mathrm{~d}$ after transplant (Tables 11 and 12). $\mathrm{NO}_{3}-\mathrm{N}$, DIP, $\mathrm{Ca}$, and $\mathrm{Fe}$ concentrations had increased between the 14th and 69th $\mathrm{d}$ after transplant. $\mathrm{K}$ concentration was higher in the $25 \mathrm{BC}-75 \mathrm{SD}$ and $0 \mathrm{BC}-100 \mathrm{SD}$ substrates but lower in all other substrates when the second solution extraction was conducted. $\mathrm{Mg}$ concentration in the 75BC-25SD and 50BC-50SD substrates decreased, but increased in all other substrates between the first and second solution extractions. The concentration of $\mathrm{NO}_{3}-\mathrm{N}, \mathrm{DIP}, \mathrm{K}$, $\mathrm{Mg}$, and $\mathrm{Fe}$ in the fertigation solution was considerably higher $69 \mathrm{~d}$ after transplant compared with $14 \mathrm{~d}$ after transplant, whereas the concentration of $\mathrm{Ca}$ was lower.

Some trends relating soluble nutrient content in substrate solution to the proportion of 
biochar contained in the substrates also differed between the 14th and 69th d after transplant (Tables 9 and 10). Fourteen day after transplant, $\mathrm{K}, \mathrm{Mg}$, and DIP concentrations increased with increasing proportions of biochar in the substrate, but this trend was not apparent in regard to $\mathrm{K}$ or $\mathrm{Mg}$ and had reversed for DIP by the 69th $\mathrm{d}$ after transplant. The trend of increasing $\mathrm{NO}_{3}-\mathrm{N}$ with increased proportions of biochar in the substrate, that was present $14 \mathrm{~d}$ after transplant, remained at the time of the second extraction. So had the trend of all substrates containing biochar having a lower Fe concentration than the 0BC-100SD substrate (Tables 9 and 10). The lack of an apparent trend relating to $\mathrm{Ca}$ concentration and the proportion of biochar in the substrate was consistent both times that extractions were conducted.

\section{Discussion}

Biochar characterization. The properties of biochar produced from tomato crop green waste were generally as would be expected based on the literature. Total biochar yield was comparable to that obtained from a range of materials produced at similar temperatures including nut shells, wood wastes, and poultry litter (Calvelo Pereira et al., 2011; Kinney et al., 2012; Novak et al., 2009). $\mathrm{C}_{\text {total }}, \mathrm{C}_{\text {fixed }}, \mathrm{N}_{\text {total }}$, and ash content of tomato crop green waste biochar fell between what is typical of biochars made from woody plant materials, and those made from animal manures and biosolids (Calvelo Pereira et al., 2011; Novak et al., 2009; Singh et al., 2010; Wang et al., 2012).

The $\mathrm{pH}$ of tomato crop green-waste biochar was higher than that of biochar produced from other similar forms of green waste (pepper; grass clippings, plant prunings), and was much more similar to that of biochar derived from manures (Chan et al., 2008; Harel et al., 2012; Singh et al., 2010; Wang et al., 2012). In addition, $K$ content was between 20 and 40 times greater than that of biochar derived from eucalyptus wood, and twice that found in cow manure and poultry litter biochar produced at the same temperature (Singh et al., 2010). FA-P content of tomato crop green-waste biochar was also about twice that found in cow manure biochar (Wang et al., 2012). The high FA-P content of tomato crop green-waste biochar would suggest that there is potential to exploit the biochar as a source of P. According to WDPT categories used for evaluation of soil, the biochar produced from our first batch would be considered hydrophilic (Bisdom et al., 1993); this would not be the case for the second batch. The presence of incompletely carbonized material, such as tomato oils remaining in the biochar, most probably contributed to this hydrophobicity. However, as discussed below, this hydrophobicity was overcome when mixing biochar with sawdust.

Substrate characterization. Physical analysis of the substrates containing, or consisting entirely of, biochar produced from tomato crop green waste, indicated that for most measured properties they are suitable material for soilless, hydroponic tomato production. Both WHC and AFP of all substrates meet Australian Standards for potting mixes and these properties, as well as $\mathrm{BD}$, fell within a range that would be considered normal for soilless substrates (Australian Standards International, 2003; Blok et al., 2008). Usually, lower BD is accompanied by higher TP, but the results of this experiment indicate that both $\mathrm{BD}$ and TP (WHC + AFP) of the 100BC-0SD substrate were lower than the 0BC-100SD substrate (Blok et al., 2008). Because WHC and AFP are calculated based on the quantity of water absorbed by the substrate after saturation, if pores are strongly hydrophobic, they will not absorb water, and as a result both WHC and AFP may be understated (Raviv et al., 2002). Owing to the highly hydrophobic nature of the biochar used in the substrates this is very likely, despite the substrates being saturated for a much longer period than is recommended for the method used (Australian Standards International, 2003).

The highly porous nature of biochar (Atkinson et al., 2010; Downie et al., 2009) combined with the large proportion of very fine particles contained in the tomato crop green-waste biochar may explain why the WHC of the 100BC-0SD substrate was higher than the WHC of the 0BC-100SD substrate. However, if the biochar contains a large proportion of micropores with strong capillary action a considerable proportion of the water held in the substrate after draining may not be available to plants (Herath et al., 2013). More research is required to evaluate the pore size distribution of biochar produced from tomato crop green waste and to establish the easily available water (EAW) content of substrates that contain this material. A potential advantage of biochar as a substrate is that water-holding and aeration characteristics can be manipulated relatively easily. The potential to manipulate biochar physical characteristics through grading particles sizes and/or pelletising to improve the suitability of such a material for use as a soilless substrate should not be disregarded.

All substrates had good wettability characteristics except the 100BC-0SD substrate. The poor carbonization of the second batch of biochar contributed to this effect. Though the WDPT test was used to evaluate wettability, instead of the Australian Standards method, it is very unlikely that the $100 \mathrm{BC}-0 \mathrm{SD}$ substrate would have met the requirements for potting mixes (Australian Standards International, 2003). It is interesting that the substrates containing mixes of biochar and sawdust were so much less hydrophobic than the 100BC-0SD substrate, and were also slightly less hydrophobic than the 0BC$100 \mathrm{SD}$ substrate. Further research is required to understand the mechanisms behind this result.

Chemical analysis of the substrates showed that although biochar has a very high natural EC, and none of the biocharcontaining substrates met the Australian
Standards for potting mixes (Australian Standards International, 2003), this can be effectively lowered by leaching with water. In fact, after leaching, the EC of all substrates was below $0.5 \mathrm{mS} \cdot \mathrm{cm}^{-1}$ and could be considered to be acceptable for use as a soilless, hydroponic substrate. Moreover, it may be possible to capture, with the intention of recycling, a substantial quantity of nutrient salts during this leaching pretreatment.

The high $\mathrm{pH}$ of substrates containing biochar is a significant concern regarding its use as a soilless substrate. Though the $\mathrm{pH}$ values of all substrates containing biochar was slightly reduced after leaching, the $\mathrm{pH}$ of these substrates remained $>7$, thus above the range of 5.3-6.5 required to meet Australian Standards for potting mixes (Australian Standards International, 2003). This was also the case for the $0 \mathrm{BC}-100 \mathrm{SD}$ substrate. The $\mathrm{pH}$ of this substrate actually increased after leaching, and is most likely due to the removal of soluble organic acids from the sawdust during leaching (Macdonald and Dunn, 1953; Weil et al., 1997). It has been demonstrated that pretreating substrate materials, by washing with an acid solution before use, will lower $\mathrm{pH}$ and therefore improve the suitability of materials with high $\mathrm{pH}$ for use as soilless substrates (Blok et al., 2011; Urrestarazu et al., 2003). The feasibility of doing this at the greenhouse scale with biochar substrates should be investigated.

Plant growth performance. Results indicate that biochar produced from tomato crop green waste performs as well as pine sawdust as a substrate for soilless, hydroponic tomato production. The lack of significant differences between substrates for the plant growth, yield, and fruit quality indicators, despite the considerable differences in the $\mathrm{pH}$ of the solution extracted from the different substrates was unexpected. On the day of transplant, the $\mathrm{pH}$ of the solution extracted from the 100BC-0SD substrate was $>10$, and remained $>9$ until $\approx 35 \mathrm{~d}$ after transplant. Over the same period, the $\mathrm{pH}$ of the $0 \mathrm{BC}$ 100SD substrate solution ranged from 6.5 to 7.8. Dyśko et al. (2008, 2009) observed, working with tomato crops grown in fertigated soilless substrates (with no specific nutrient management to account for high $\mathrm{pH})$, that increasing the $\mathrm{pH}$ of the nutrient solution from 5.5 to 6.5 results in a $13 \%$ reduction in yield as well as decreased leaf tissue $P$ content, and available $P$ concentration in substrate solution. In contrast, Islam et al. (1980) found no differences in growth or biomass production between tomato plants grown at a $\mathrm{pH}$ of 5.5 or 8.5 when produced in a nutrient flow system, with no specific nutrient management to account for high $\mathrm{pH}$. It was also found that compared with those grown at $\mathrm{pH}$ of 5.5, tomato shoot tissue of plants grown at a $\mathrm{pH}$ of 8.5 had increased $\mathrm{Mg}, \mathrm{K}$, and $\mathrm{N}$, but decreased $\mathrm{P}$ content, while Fe levels were similar (Islam et al., 1980), which correlates well with our results. $\mathrm{Fe}$ underwent a rather drastic drop in nutrient concentration, as compared with the $0 \mathrm{BC}$ 100SD treatment. However, there were no 
differences between substrates in terms of leaf tissue $\mathrm{Fe}$ among treatments. It is possible that the fertigation regime used in the main growth trial provided enough nutrients to overcome any reduction in availability occurring due to high $\mathrm{pH}$ of the substrates. However, there are few contemporary studies exploring the effects of high $\mathrm{pH}$ on plant growth in modern fertigated soilless culture, particular with $\mathrm{pH}$ values as high as 10 . As far as is known, this is one of the first studies, which has investigated the effect of such high $\mathrm{pH}$ in a system that uses biochar as a substrate material. It is not yet clear if there is a specific effect of biochar that prevents growth inhibition at high $\mathrm{pH}$, or an alternative mechanism is responsible. Certainly, any reliable growth modification response mediated by biochar could be a valuable agronomic tool, provided such responses could be standardized according to biochar feedstocks of course.

The only visible sign of any nutrientrelated issues during the main growth trial was limited occurrence of BER, which is related to Ca supply (Morgan, 2008). However, Ca content of leaf tissue harvested $42 \mathrm{~d}$ after transplant did not vary significantly between substrates. This was despite $\mathrm{Ca}$ concentration of the solution extracted from the 100BC-0SD substrate $14 \mathrm{~d}$ after transplant being nine times lower than the fertigation solution. BER affected less than $1 \%$ of the crop and the frequency at which it occurred could not be related to the proportion of biochar in the substrate. Furthermore, BER is a complicated condition and cannot be solely attributed to Ca concentration in substrate solution (Ho and White, 2005). Conducting leaf tissue and fruit nutrient content analysis at a later stage of the crop growth period to investigate whether any differences in nutrient content or partitioning develop later in the crop cycle would be worthwhile in future research.

The only confirmed differences in plant growth that could be attributed to the proportion of biochar contained in the substrate were the higher $\mathrm{K}$ and $\mathrm{Mg}$ content of leaf tissue samples collected $42 \mathrm{~d}$ after transplant from plants grown in biochar relative to those grown in sawdust. The results suggest that $\mathrm{K}$ and $\mathrm{Mg}$ not leached from the biochar during pretreatment resulted in higher $\mathrm{K}$ and $\mathrm{Mg}$ concentration in the substrate solution of modules containing high proportions of biochar. This is supported by analysis of the substrate solution extracted $15 \mathrm{~d}$ after transplant and may explain the higher EC of solution extracted from modules with increased proportions of biochar $35 \mathrm{~d}$ after transplant. Increased concentrations of $\mathrm{K}$ and $\mathrm{Mg}$ in nutrient solution are known to result in greater plant uptake of these minerals (Pujos and Morard, 1997). Though $\mathrm{K}-\mathrm{Mg}$ antagonism is recognized as an issue in a number of crops, it has been found that the concentration of either element in tomato leaves increases in response to increased concentration of that element even when of the concentration of the other element is increased (Kabu and Toop, 1970; Pujos and Morard, 1997). K-Ca antagonism has also been identified as a problem in some crops, but it has been shown that $\mathrm{Ca}$ content of tomato leaves is unaffected by increased $\mathrm{K}$ supply (Pujos and Morard, 1997), which is supported by the results of this growth trial.

Substrate module analysis. Overall, results from the analysis of substrate module VWC confirmed that the tomato crop greenwaste biochar had a higher WHC than the sawdust. The very low VWC of all substrate modules $102 \mathrm{~d}$ after transplant was the result of poor fertigation management. The $\mathrm{pH}$ of all the substrate modules containing biochar decreased considerably over the course of the main growth trial. By the end of the growth trial, the $\mathrm{pH}$ of all except the 100BC-0SD and the 75BC-25SD substrates were within the range that meets the Australian Standards for potting mixes (Australian Standards International, 2003). However, at no time was $\mathrm{pH}$ close to what would normally be considered ideal for tomato production (Morgan, 2008). The rate at which the $\mathrm{pH}$ of the substrate solutions decreased did not change substantially after the $\mathrm{pH}$ of the fertigation solution was managed so that it remained $<6$. This brings in to question how effective this method was at modifying substrate solution $\mathrm{pH}$. The $\mathrm{pH}$ of the substrates containing $\geq 75 \%$ sawdust increased over the first 2 weeks, which is most likely due to leaching of soluble organic acids in the sawdust that were not rinsed during pretreatment (Macdonald and Dunn, 1953; Weil et al., 1997).

Throughout the main growth trial, the EC of the solution extracted from substrates generally increased as the proportion of biochar contained in the substrate increased. In addition, except on the day of transplant, the EC of the 100BC-0SD substrate solution was higher than that of the fertigation solution on the every occasion that measurements were taken over the first $21 \mathrm{~d}$ after transplant. High substrate solution EC relative to fertigation solution EC has been observed with other substrate materials, and is often due to poor flushing of excess nutrients from substrates through inadequate fertigation applications (Komosa et al., 2009). It is possible that the greater WHC of the biochar, relative to the sawdust, may have resulted in reduced drainage from substrate modules containing biochar. As a consequence, excess nutrient salts would have been less effectively leached from the substrates that contained biochar. It is also possible that during the initial stages of the growth period, the high soluble salt content and hydrophobic nature of the biochar were contributing factors. If biochar particles were not yet thoroughly wetted, this may have resulted in additional salts being dissolved into substrate solution, as increasing proportions of the biochar became wet. Though these mechanisms would be antagonistic to some degree, it is possible that both occurred simultaneously. The issue of high solution EC in substrates produced from tomato crop green-waste biochar could be overcome by 1) producing biochar with better wettability characteristics, 2) refining the pretreatment process to ensure all soluble salts are removed, 3) tailoring the fertigation program to better suit the water-holding characteristics of the biochar substrate, and 4) diluting the fraction of tomato green waste of the feedstock with a woody green waste.

Inadequate leaching of nutrient salts is also the most likely reason for the very high EC of the solutions extracted from all substrates $110 \mathrm{~d}$ after transplant. Poor irrigation management in the final stages of the main growth trial led to very low VWC, as seen $102 \mathrm{~d}$ after transplant. This would have caused a large accumulation of soluble salts in all substrates. These salts were not thoroughly leached from the substrates over the course of subsequent fertigation applications.

Despite the lack of effects on plant growth, there were considerable differences in the concentrations of individual nutrients contained in solution extracted from each of the substrates. $\mathrm{NO}_{3}-\mathrm{N}$ concentration of solution extracted from the substrates containing $\geq 50 \%$ sawdust was lower than the fertigation solution on both occasions that it was measured. This is commonly observed with organic substrates, and is the result of $\mathrm{N}$-immobilization from biological decomposition (Morgan and Lennard, 2008). This is also the likely cause of the lower EC of the 0BC-100SD substrate solution relative to the fertigation solution that occurred for most of the growth trial. As previously mentioned, biochar was most likely contributing $\mathrm{K}$ and $\mathrm{Mg}$ during the early stages of the growth trial, and causing reduced $\mathrm{Fe}$ concentration throughout the entire growth trial. Sixty nine $d$ after transplant the biochar was also causing a reduction in $\mathrm{P}$ concentration, which is likely to be an effect of high $\mathrm{pH}$ (Adams, 1986). However, $14 \mathrm{~d}$ after transplant, $P$ concentration increased with increasing proportion of biochar in the substrate, despite the high $\mathrm{pH}$. This may be explained if the biochar was contributing significant quantities of $\mathrm{P}$ to substrate solution during the early period of the growth trial, which is feasible given the high available $\mathrm{P}$ content of the biochar, as revealed by the formic acid extraction.

\section{Conclusions and Implications for Food Production}

The findings from this research indicate that biochar produced from tomato crop green waste is suitable for use as a substrate for soilless, hydroponic tomato production. Tomatoes grown in substrates containing, or consisting entirely of biochar do not differ significantly in terms of growth, yield, or fruit quality to those grown in pine sawdust, a substrate that is currently used for commercial tomato production. The only differences observed between plants grown in sawdust and biochar substrates were increased $\mathrm{K}$ and $\mathrm{Mg}$ concentrations found in the leaf tissue of plants grown in substrates containing higher proportions of biochar. This is most likely due to the presence of residual nutrient salts 
in the biochar. Results from our study also indicate that many of the relevant properties of substrates containing, or consisting entirely of biochar produced from tomato crop green waste represent potentially valuable characteristics of a hydroponic substrate. Water-holding and aeration characteristics were acceptable and there is further potential to optimize these through processing and grading. The EC of substrates containing, or consisting entirely of biochar was easily reduced to an acceptable level by rinsing with water before use, and there is potential to capture and recycle nutrients flushed during this process. Although more research is required, the high $\mathrm{pH}$ of substrates containing biochar did not affect any of the plant growth, yield, and fruit quality indicators that were measured during this trial.

The results of our study support the concept of creating a closed loop system whereby biochar produced from tomato crop green waste is used as a substrate for soilless, hydroponic tomato production. Furthermore, indications are that it would be relatively easy to integrate such a concept into certain existing commercial production systems. The utilization of biochar produced from tomato crop green waste as a soilless substrate could have considerable advantages for greenhouse tomato growers. Turning tomato crop green waste to biochar would divert $10-60 \mathrm{t} \cdot \mathrm{ha}^{-1}$ of green waste away from land fill each crop cycle. If the assumption is made that the green-waste biochar is produced at $550{ }^{\circ} \mathrm{C}$, it would meet $13 \%$ to $50 \%$ of the grower's substrate requirements, on a per hectare basis. Pyrolysis of green waste could result in excess energy, in the form of syngas and biooil, which can be used to supplement glasshouse energy requirements. This could be done by either capturing and storing the fuel, or burning it during pyrolysis and storing the energy in the heat storage tanks that are commonly a component of greenhouse heating systems (Nederhoff and Houter, 2007). In addition, if biochar is incorporated into the $\mathrm{C}$ market, the stable $\mathrm{C}$ fraction could be eligible for $\mathrm{C}$ credits. Combined with the decreased emissions that will result from using the fuel produced during pyrolysis, this is likely to represent a considerable reduction in the $\mathrm{C}$ footprint associated with glasshouse tomato production. After biochar has been used as a substrate, the residual agronomic value could be exploited by other agricultural sectors as a soil amendment, or as a raw material for composts or potting mixes. However, a thorough analysis of the economic and practical feasibility of such a concept is required at this time, as well as a life cycle analysis (LCA) so that the environmental impact associated with the production, use, and disposal of biochar substrates is compared with regular substrates such as coco coir or rockwool. Finally, foodstuffs produced on a biochar substrate composed of production components such as polypropylene string will require food safety and acceptability assessments. Future attention is also needed regarding how pyrolysis technology can be best incorporated into glasshouse production systems to maximize the financial and environmental benefits that can be obtained.

\section{Literature Cited}

Adams, P. 1986. Mineral nutrition, p. 281-334. In: J.G. Atherton and J. Rudich (eds.). The tomato crop. Chapman and Hall, London.

Ahmedna, M., M.M. Johns, S.J. Clarke, W.E. Marshall, and R.M. Rao. 1997. Potential of agricultural by-product-based activated carbons for use in raw sugar decolourisation. J. Sci. Food Agr. 75:117-124.

Allaire, S., J. Caron, C. Ménard, and M. Dorais 2004. Growing media varying in particle size and shape for greenhouse tomato. Acta Hort. 644:307-311.

Allaire, S., J. Caron, C. Ménard, and M. Dorais. 2005. Potential replacements for rockwool as growing substrate for greenhouse tomato. Can. J. Soil Sci. 85:67-74.

AOAC. 1975. Association of official agricultural chemists: Official analysis. 12th ed. AOAC, Washington, DC.

Atkinson, C.J., J.D. Fitzgerald, and N.A. Hipps. 2010. Potential mechanisms for achieving agricultural benefits from biochar application to temperate soils: A review. Plant Soil 337: $1-18$.

Australian Standards International. 2003. Australian standard: Potting mixes. Australian Standards International Ltd, Sydney, Australia.

Bisdom, E.B.A., L. Dekker, and J.F.Th. Schoute. 1993. Water repellency of sieve fractions from sandy soils and relationships with organic material and soil structure. Geoderma 56:105-118.

Blok, C., C. De Kreij, R. Baas, and G. Wever. 2008. Analytical methods used in soiless cultivation, p. 245-289. In: M. Raviv and J.H. Lieth (eds.). Soilless culture theory and practice. Elsevier Science, Boston, MA

Blok, C., A. van Winkel, and S. Chizhmak. 2011. Glass foam granulate as growing medium for tomato and cucumber. Acta Hort. 891:215222.

Bundy, L.G. and J.M. Bremner. 1972. A simple titrimetric method for determination of inorganic carbon in soils. Soil Sci. Soc. Amer. J. 36:273-275

Calvelo Pereira, R., J. Kaal, M. Camps-Arbestain, R. Pardo Lorenzo, W. Aitkenhead, M. Hedley, F. Macias, J. Hindmarsh, and J. Maciá-Agulló 2011. Contribution to characterisation of biochar to estimate the labile fraction of carbon. Org. Geochem. 42:1331-1342.

Canizares, K.A.L., P.C. Costa, R. Goto, and A.R.M. Vieira. 2002. Development of cucumber seedlings in different substrates with and without nutritive solution. [Desenvolvimento de mudas de pepino em diferentes substratos com e sem uso de solucao nutritiva.] Hort. Bras. 20:227229.

Carrijo, O.A., M.C. Vidal, N.V.B. Reis, R.B Souza, and N. Makishima. 2004. Tomato crop production under different substrates and greenhouse models. [Produtividade do tomateiro em diferentes substratos e modelos de casas de vegetacao.] Hort. Bras. 22:5-9.

Chan, K.Y., L. van Zwieten, I. Meszaros, A. Downie, and S. Joseph. 2008. Agronomic values of greenwaste biochar as a soil amendment. Austral. J. Soil Res. 45:629-634.

Downie, A., A. Crosky, and P. Munroe. 2009. Physical properties of biochar, p. 13-32. In: J. Lehmann and S. Joseph (eds.). Biochar for environmental management: Science and technology. Earthscan, Sterling, VA.

Dumroese, R.K., J. Heiskanen, K. Englund, and A. Tervahauta. 2011. Pelleted biochar: Chemical and physical properties show potential use as a substrate in container nurseries. Biomass Bioenergy. doi: 10.1016/j.biombioe.2011.01.053.

Dyśko, J., S. Kaniszewski, and W. Kowalczyk. 2008. The effect of nutrient solution $\mathrm{pH}$ on phosphorus availability in soilless culture of tomato. J. Elem. 13:189-198.

Dyśko, J., W. Kowalczyk, and S. Kaniszewski. 2009. The influence of $\mathrm{pH}$ of nutrient solution on yield and nutritional status of tomato plants grown in soilless culture system. Veg. Crops Res. Bull. 70:59-69.

Elad, Y., D.R. David, Y.M. Harel, M. Borenshtein, H.B. Kalifa, A. Silber, and E.R. Graber. 2010. Induction of systemic resistance in plants by biochar, a soil-applied carbon sequestering agent. Phytopathology 100:913-921.

Godfray, H.C.J., J.R. Beddington, I.R. Crute, L. Haddad, D. Lawrence, J.F. Muir, J. Pretty, S. Robinson, S.M. Thomas, and C. Toulmin. 2010. Food security: The challenge of feeding 9 billion people. Science 327:812-818.

Graber, E.R., Y.M. Harel, M. Kolton, E. Cytryn, A. Silber, D.R. David, L. Tsechansky, M. Borenshtein, and Y. Elad. 2010. Biochar impact on development and productivity of pepper and tomato grown in fertigated soilless media. Plant Soil 337:481-496.

Guerrini, I.A. and R.M. Trigueiro. 2004. Physical and chemical attributes of substrates composed of biosolids and carbonized rice chaff. [Atributos fisicos e quimicos de substratos compostos por biossolidos e casca de arroz carbonizada.] Rev. Bras. Cienc. Solo 28:10691076.

Harel, M.Y., Y. Elad, D. Rav-David, M. Borenstein, R. Shulchani, B. Lew, and E.R. Graber. 2012. Biochar mediates systemic response of strawberry to foliar fungal pathogens. Plant Soil 357:245-257.

Herath, H.M.S.K., M. Camps Arbestain, and M. Hedley. 2013. Effect of biochar on soil physical properties in two contrasting soils: An Alfisol and an Andisol. Geoderma 209-210:188-197.

Ho, L.C. and P.J. White. 2005. A cellular hypothesis for the induction of blossom-end rot in tomato fruit. Ann. Bot. (Lond.) 95:571-581.

IBI. 2012. Standardized product definition and product testing guidelines for biochar that is used in soil. International Biochar Initiative. 1 Dec. 2013. <http://www.biochar-international. org/>.

Ikeda, H. 1985. Soilless culture in Japan. Farm. Jpn 19:36-42.

Inden, H. and A. Torres. 2004. Comparison of four substrates on the growth and quality of tomatoes. Acta Hort. 644:205-210.

International Society for Horticultural Science (ISHS). 2012. Harvesting the Sun-a profile of World Horticulture. ISHS, Belgium, Europe.

Islam, A.K.M.S., D. Edwards, and C. Asher. 1980. pH optima for crop growth. Plant Soil 54:339357.

John, M.K. 1970. Colorimetric determination of phosphorous in soil and plant materials with ascarbic acid. Soil Sci. 109:214-220.

Kabu, K.L. and E. Toop. 1970. Influence of potassium-magnesium antagonism on tomato plant growth. Can. J. Plant Sci. 50:711-715.

Kämpf, A.N. and M. Jung. 1991. The use of carbonized rice hulles as an horticultural substrate. Acta Hort. 294:271-284.

Keith, L.H. 1992. Water quality parameters, p. 739-762. In: L.H. Keith (eds.). Compilation of 
E.P.A.'s sampling and analysis methods. Lewis Publishers, Chelsea, MI.

Kinney, T., C. Masiello, B. Dugan, W. Hockaday, M. Dean, K. Zygourakis, and R. Barnes. 2012. Hydrologic properties of biochars produced at different temperatures. Biomass Bioenergy 41:34-43.

Komosa, A., J. Piróg, and T. Kleiber. 2009. Changes of macro and micronutrients contents in the root environment of greenhouse tomato grown in fiber wood. Veg. Crops Res. Bull. 70:71-80.

Lee, B., J. Cho, S. Park, J. Ahn, and S. Chung. 1999. Effects of substrates on the growth and fruit quality of hydroponically grown tomatoes, Lycopersicon esculentum Mill. cv. Katinka. Act. Hort. 483:147-153.

Letey, J. 1969. Measurement of Contact Angle, Water Drop Penetration Time and Critical Surface Tension. Proceedings of the symposium on water-repellent soils, Univ. of California, May 1968, p. 43-47.

Macdonald, W.A. and S. Dunn. 1953. Sawdust composts in soil improvement. II. Pot culture studies with compost mixtures of sawdust and manure, steam treated composts, and miscellaneous mixtures. Plant Soil 4:235-247.

Matsue, N. and K. Wada. 1985. A new equilibration method for cation-exchange capacity measurement. Soil Sci. Soc. Amer. J. 49:574-578.

Morgan, L. 2008. Hydroponic tomato crop production. Suntec International Hydroponic Consultants, Tokomaru, New Zealand.

Morgan, L. and S. Lennard. 2008. Evaluation of $\mathrm{NZ}$ scoria product as a commercial growing media for hydroponic tomato production. Suntec International Hydroponic Consultants, Tokomaru, New Zealand.
Murphy, J. and J.P. Riley. 1962. A modified single solution method for determination of phosphate in neutral waters. Anal. Chim. Acta 27:31-36.

NCDA\&CS. 2011. Tissue sampling and analysis for greenhouse tomatoes. 6 May 2011. <www. ncagr.gov/agronomi/pdffiles/gtomato.pdf $>$.

Nederhoff, E. and B. Houter. 2007. Improving energy efficiency in greenhouse vegetable production. Final Report on project SFF 03/158. Horticulture New Zealand, Wellington.

Neocleous, D. and P. Polycarpou. 2010. Gravel for soilless tomato culture in the Mediterranean region. Intl. J. Veg. Sci. 16:148-159.

Nishimura, Y., C.A.G. Ballila, Y. Fukumoto, M. Murail, and M.T. Barnor. 2009. Study on the seedling traits of eggplant grown in several different types of nursery culture media. Hort. Environ. Biotechnol. 50:100-103.

Novak, J.M., I. Lima, B. Xing, J.W. Gaskin, C. Steiner, K. Das, M. Ahmedna, D. Rehrah, D.W Watts, W.J. Busscher, and H. Schomberg. 2009. Characterization of designer biochar produced at different temperatures and their effects on a loamy sand. Ann. Environ. Sci. 3:195-206.

Peyvast, G., J.A. Olfati, P.R. Kharazi, and O.N. Roudsari. 2010. Effect of substrate on greenhouse cucumber production in soilless culture. Acta Hort. 871:429-436.

Piper, C. 1950. The determination of calcium carbonate; rapid titration method, p. 135-136. Soil and Plant Analysis. Interscience, New York, NY.

Pires, C.R.F., L.C.O. Lima, E.V.B.V. Boas, and R. R. Alves. 2009. Textural quality of tomatoes grown in organic substrates subjected to application of humic substances. [Qualidade textural de tomates cultivados em substratos organicos submetidos a aplicacao de substancias humicas.] Pes. Agron. Bras. 44:1467-1472.

Pujos, A. and P. Morard. 1997. Effects of potassium deficiency on tomato growth and mineral nutrition at the early production stage. Plant Soil 189:189-196.

Raviv, M., R. Wallach, A. Silber, A. Bar-Tal, and D. Savvas. 2002. Substrates and their analysis, p. 25-101. In: D. Savvas and H. Passam (eds.). Hydroponic production of vegetables and ornamentals Embryo publications, Athens, Greece.

Ruifen, Q., Z. Dewei, X. Zhihao, Y. Genhua, and M. Yonghua. 1991. Effects of soilless culture substrates on the physiology and yield of tomato. Acta Agr. Zhejiangensis 2. doi: Cnki: sun:zjnb.0.1991-02-006.

Scheiner, D. 1976. Determination of ammonia and Kjeldahl nitrogen by indophenol method. Water Res. 10:31-36.

Singh, B., B.P. Singh, and A.L. Cowie. 2010. Characterisation and evaluation of biochars for their application as a soil amendment. Soil Res. 48:516-525.

Urrestarazu, M., M.C. Salas, and P. Mazuela. 2003. Methods of correction of vegetable waste compost used as substrate by soilless culture. Acta Hort. 609:229-233.

Wang, T., M. Camps-Arbestain, M. Hedley, and P. Bishop. 2012. Predicting phosphorus bioavailability from high-ash biochars. Plant Soil 357:173-187.

Weil, J., A. Sarikaya, S.L. Rau, J. Goetz, C.M. Ladisch, M. Brewer, R. Hendrickson, and M.R. Ladisch. 1997. Pretreatment of yellow poplar sawdust by pressure cooking in water. Appl. Biochem. Biotechnol. 68:21-40. 